Int. J. Electrochem. Sci., 16 (2021) Article ID: 210653

International Journal of

ELECTROCHEMICAL

SCIENCE

$\underline{\text { www.electrochemsci.org }}$

\title{
Comparative Study on the Morphology and Electrochemical Performance of Self-made and Commercial $\mathrm{LiNi}_{0.5} \mathrm{Mn}_{1.5} \mathrm{O}_{4}$ Electrode
}

\author{
Jinjing Du ${ }^{1,2, *}$, Meng Zhou ${ }^{l}$, Xingliang Zhang ${ }^{1}$, Zhao Fang ${ }^{1,2}$, Bin Wang ${ }^{1}$, Qian Li $^{l}$,Yuehao Guo ${ }^{1}$, \\ Zhuoqi Liu ${ }^{I}$ \\ ${ }^{1}$ School of Metallurgy Engineering, Xi'an University of Architecture and Technology \\ ${ }^{2}$ Research Center of Metallurgical Engineering and Technology of Shaanxi, Xi'an 710055, China \\ *E-mail: djzxauat@gmail.com
}

doi: $10.20964 / 2021.06 .47$

Received: 19 February 2020 / Accepted: 12 April 2021 / Published: 30 April 2021

The $\mathrm{LiNi}_{0.5} \mathrm{Mn}_{1.5} \mathrm{O}_{4}$ high voltage cathode for lithium ion batteries is prepared via simple co-precipitation method. The effect of the precipitation temperature, $\mathrm{pH}$, and calcination temperature on the phase transformation, microstructure and electrochemical performance was investigated. On this basis, a comparative study on the morphology and electrochemical properties of the prepared and commercial $\mathrm{LiNi}_{0.5} \mathrm{Mn}_{1.5} \mathrm{O}_{4}$ cathodes was also conducted. The results indicate that the high-purity precursor was obtained with preparation $\mathrm{pH}$ and temperature is 11.5 and $50^{\circ} \mathrm{C}$, and then was mixed and ground with $\mathrm{LiOH}$ thoroughly, and then the mixture was calcined at $800{ }^{\circ} \mathrm{C}$ for 15 hours to obtain $\mathrm{LiNi}_{0.5} \mathrm{Mn}_{1.5} \mathrm{O}_{4}$ material, which demonstrated superior performance. Both the commercial and self-made lithium nickel manganate cathode materials present typical spinel structure. Obvious particle agglomeration for poor dispersion could be observed in the commercial lithium nickel-manganate cathode material. The particles are dispersed uniformly, but some large-sized particles appeared in prepared cathode material. The initial discharge capacity is about $128.2 \mathrm{mAh} / \mathrm{g}$ at a rate of $1 \mathrm{C}$. After 100 cycles, the capacity retention of the prepared lithium nickel-manganate cathode material is $93.8 \%$, while a lower capacity retention of $92.5 \%$ for the commercial cathode material.

Keywords: Lithium-ion batteries; Spinel $\mathrm{LiNi}_{0.5} \mathrm{Mn}_{1.5} \mathrm{O}_{4}$; Cathode; Electrochemical performance

\section{$\underline{\text { FULL TEXT }}$}

(C) 2021 The Authors. Published by ESG (www.electrochemsci.org). This article is an open access article distributed under the terms and conditions of the Creative Commons Attribution license (http://creativecommons.org/licenses/by/4.0/). 